\title{
The Travels of Sir John Mandeville and the Moral Geography of the Medieval World
}

\section{Charles Moseley, University of Cambridge}

Mandeville's Travels ${ }^{1}$ began to circulate soon after 1356 . Though nobody is sure who wrote it, few would now give any credit to the uncompromising declaration by one of the book’s first editors, Paul Hamelius, that it was a Liège notary, Jean d'Outremeuse, ${ }^{2}$ any more than to the suggestion it was a certain doctor, known to have practised in Liège, Jean de Bourgogne. ${ }^{3}$ The book's narrator affirms that he is an English knight. That is not impossible, as there was a growing class of milites literati, and there are several details that suggest an intimate acquaintance with England. But it is certain that the author, whoever he was, and it does not really matter, had the use of the resources of a good library and was moreover very much au fait with contemporary religious issues and controversies. Some Mandeville scholars believe he was connected with a Benedictine called Jean le Lonc, of Ypres, who wrote a collection of material on the Near and Far East (including travel narratives). To that collection it is certain Mandeville had access. Seymour has suggested, indeed—most recently in his 2010 edition of the Egerton Version-that Jean and 'Mandeville' were one and the same person. The question of who wrote it, however, does not affect an appreciation of this

\footnotetext{
1 A list of the most important editions and the fullest discussions of the book is given at the end of this essay.

${ }^{2}$ This idea, utterly simplistic, was first suggested by Hamelius (1919) on the title page in his edition and he adduced the slimmest of evidence to support it.

${ }^{3}$ De Bourgogne is known to be the author of a treatise De Pestilentia, and is named in certain MSS of the Travels. But there are several early MSS of great authority-mainly those circulating in England—which make no mention of him. His authorship can be discounted.
} 
complex book, the importance of which is beyond question. It was, after all, by far the most widely disseminated account of the Orient in the later Middle Ages and early modern period, and was frequently adapted for various different uses. It was one of the first secular books to be printed, and printers do not print for fun: they knew there was a demand.

The book was almost certainly written originally in Anglo-Norman. Versions in other languages appeared very shortly afterwards: in Paris French (1371), Latin (the 'Vulgate' text), German (1393), and English. There are three English translations that can be dated just before or just after 1400: The Cotton and Egerton versions; and the so-called Defective Version, which has a large lacuna in the description of Egypt. The account, in whole or in part, was regularly included in summae that had as their theme the countries of the East, like the Livre des Merveilles (1403) in the Bibliothèque Nationale. But it was also recast, for example as a picture book, at the beginning of the fifteenth century (British Library Addit M.S. 24189), or even as a verse narrative, like the English Metrical Version (ed. M. C. Seymour 1973). Well before the end of the fifteenth century one could have got hold of the book in every major language of Europe, including Czech and Irish. At least 300 MSS actually survive. (Just for comparison, of Marco Polo there are only some 70.) After printing, the book was regularly reissued: in England, and from 1568 (at least) down to about 1710, there was an edition roughly every 13 years. ${ }^{4}$ Very few other books in English from the Middle Ages made it into the shops of early printers-Chaucer, Langland, Lydgate are almost the only others-and no other medieval book was reissued so often for so long.

All these versions show to some degree —-sometimes to a large degree!_-adaptation and what one used to refer to as 'contamination.' Some of them address the special interests of a precise audience, and we should remember that our concepts of the integrity of a text, of an ideal version as it left the hand of the author, was not an idea of which anyone in the Middle Ages would have had much grasp. Paul Zumthor's concept of mouvance (1972) is really helpful: a book is continually recreated in transmission, and each recreation in its turn engenders more, which reflect the needs of that writer and his projected public. Later versions of Mandeville lose more and more the subtle nuances

\footnotetext{
4 In Moseley (2011: 5-20) I argue that though there are no surviving copies between 1496 and 1568, the existence of several can be deduced.
} 
and the values of the earliest texts. So when one tries to examine the effect of this book, known by so many over such a long period, on the mentalité of Europe, one must take into account what Iain Higgins (1997) calls its 'isotopes.' For the most part, it is impossible to say which reader read which version. The arrival of printed versions, however, seems to have normalized, in each country, the versions available on the one first printed. For example, in England after the edition of the Defective version by Pynson (1496), all editions known in English in the sixteenth and seventeenth centuries descend from Pynson's text. One sees the same normalization after the editions of 1478 and 1481 in Augsburg of Anton Sorg, or after Comeno’s 1480 Milan edition. Furthermore, it is to be noted how early these printings are: before 1500 we know of eight editions in Germany, seven in France, four in the international Latin, two in Dutch and two in English; before 1520 there are Czech and Spanish editions.

This huge popularity demands attention. The book offered something-perhaps several things - that readers were looking for. First of all, it offers itself as an account of the journey to the Holy Land and Egypt - to 'teach the way there,' as the author says. It does indeed describe several recognised pilgrim itineraries followed by pilgrims from Western Europe, and adds to them a good number of detailed anecdotes and stories about Constantinople, several islands in the Aegean, Cyprus and Egypt. It describes the monastery of St Catherine on Mount Sinai, and then, with great detail concerning the benefits in indulgence therefrom, the visits to the holy places of the Holy Land. Pilgrim narratives are not that rare and found a public among those who were preparing to make a pilgrimage — and of course many people did make the pilgrimages. But there were others who did not have the opportunity, and would use these books as a sort of mental pilgrimage with perfectly genuine devotion. Mandeville was certainly aware of this as a possible use of his book. He is careful to link places with their Biblical history and specifies in each place how many days' indulgence a devout visit and contemplation would bring. Similarly, the very circumstantial description of Jerusalem is tied closely to the Biblical accounts of the Passion and Crucifixion. Moreover, the book's prologue sounds a note which might sound very topical to late fourteenth century ears: the duty of good Christians to stop internecine conflict and unite to recover the Holy Land from the Moslems. It was, after all, only in 1291 that the last Frankish stronghold, Acre, had fallen. This was an appeal taken seriously. It bore tragic fruit in the disastrous crusade of Nicopolis in 1396, when the army of Jean sans Peur (for whom the Livre des 
Merveilles was made) was annihilated. It is important to recognise that the mental maps and attitudes of the author and of his audience were coloured not only by past crusades but also by current ones in Africa, Spain, the Eastern March and Asia Minor. Their mental maps are not spatial, as ours might be, but narrative, mnemonic and ideological.

Although this part of the book was doubtless for some readers the most important, ${ }^{5}$ it does not stop there. The narrator is made to continue his world tour across Arabia, India, and as far as Cathay, and finally to the fabulous realm of Prester John. Some places that he claims to have visited are in Indo-China or in what is now Indonesia. It is perfectly possible that the writer could have travelled that far-after all, several Westerners did so- - but this second half of the book builds almost entirely on other accounts of the Far East, earlier or contemporary, from which it has been worked up. The author knew the Letter of Prester John; he knew the Alexander Romances. He had access to the encyclopaedic Speculum Maius of Vincent of Beauvais (d. 1264)—perhaps in a big library in Flanders-which among other things dealt with accounts of travel to the East and with the natural 'Marvels of the World' descending from Pliny, Solinus and Aethicus. The first-hand account of Friar Odoric of Pordenone (1274?-1331) was especially important for Mandeville. Odoric had travelled over practically all Asia and had lived in China between 1316 and 1327. Mandeville chose from his best stories those he could elaborate to give them a new force and vividness, far greater than the original. ${ }^{6}$ For example, one need only compare Odoric's rather dull account of crossing the desert of Lop Nor with Mandeville’s far more gripping and imaginatively detailed one. (Incidentally, it is interesting to note that Mandeville seems not to have used Marco Polo.) This systematic use of the work of other writers has led a few critics to say bluntly that Mandeville's longest journey was to the nearest library, and that is indeed possible. But many real travellers_-like Schiltberger, or indeed Polo_-did flesh out their accounts in exactly this way, sometimes word for word. So it is entirely possible that some information about the Eastern Mediterranean or the Holy Land, at least, might be based on what the author himself had seen. After all, in the fourteenth century anyone with an interest in those areas would have had no difficulty in getting as far as

\footnotetext{
${ }^{5}$ One owner of the only MS (B. L. Cotton Titus cxvi) of the Cotton English translation tore out the four leaves on pilgrimage, and the picture-book version (British Library Add. M.S. 24 189), made in Prague in about 1400, only deals with this first part of the book.

${ }^{6}$ This cherry picking is exactly what happened to the Travels too, of course. Johann Schiltberger, taken prisoner at Nicopolis, used Mandeville to elaborate on his account of his own adventures.
} 
Palestine. Many people of very humble station did exactly that. Far more important, however, is the fact that for centuries no reader would have had the means to examine Mandeville's sources or incentive to question his having travelled. What people believed of the book is an important fact about it.

The second half of the book demonstrates that Mandeville passes way beyond the usual format of the pilgrim narrative. His work is a 'geographical' encyclopaedia- the term in our sense is anachronistic, of course-cast in the unusual form of a personal narrative. It is careful to offer the best information available, as trustworthy and up to date as possible, so it gives details not only of countries and cultures, but also a clear and intelligent account of the roundness of the earth, ${ }^{7}$ of the Pole Star, of the Antipodes. He asserts that the Torrid Zone of Ptolemy can in fact safely be crossed, and that moreover it is perfectly possible to sail right round the world. Indeed, he says he would himself have done it if he could have found 'company and shipping' and he claims to have met a man who had done just that.

It is in this description of the earth that Mandeville's most interesting ideas emerge, ideas that I have not been able to find in any of the sources. This constitutes one of our principal problems in understanding the book's genesis and career. For in the early texts, nothing supports the reputation that later attached to Mandeville as a mere teller of tall tales, a liar, his book full of monsters and strange beings, the 'Monsters of Men' like the Sciapods, the Astomi, 'Men whose heads do grow beneath their shoulders': in the early texts they are dismissed in a dozen lines. What instead comes over very clearly, very often, is the idea that the Nature that rules in Western Europe also rules in the rest of the world. What is impossible here is impossible there, save for the simply miraculous. As far as I can see, this is an idea unique in its time, which opens the way to serious, systematic exploration of a world which, though strange, is nevertheless comprehensible, not likely to upset the rules of nature for the traveller who goes into the unknown. By insisting on the fact that the globe is habitable everywhere, that it is everywhere traversable, the Travels encouraged people to find 'company and shipping' and set off on discovery. Which they did: it is easy to show that many who encouraged, patronised or executed the voyages of exploration of the fifteenth century, like Dom Enrique (Prince Henry the Navigator) of Portugal, or Columbus, relied on Mandeville heavily.

\footnotetext{
${ }^{7}$ Following Tractatus de Sphaera, by Johannes Sacrobosco (c. 1230).
} 
Those who went to the book for information, moreover, could not help encountering its picture of the world and its underlying ideas.

One problem can be simply stated. Without a recognised method for describing space, it becomes impossible to link countries to their neighbours. Mandeville was thus forced to adopt the convention where each country is an 'isle,' to use his word, a separate entity, and only the sensibility of the traveller as he moves from one to the other links them. This is exactly how distance and space could be envisaged in medieval accounts.

Medieval representations of space, or indeed place, can seem very strange to us. Moderns too easily assume they are simply primitive, waiting for enlightenment to happen, but the ideas our Medieval and Antique predecessors held worked as well on their terms as ours do on ours, and genuinely reflect the grammar of the way they saw. Perspective, for example, was something the Romans could manage perfectly well, as the wall paintings of Pompeii show us, but they and their successors did not always choose to use it. Just so with visualizing a space that we cannot at that moment actually see: for us moderns to do so relies on our knowledge of the convention of maps and the diagrammatic relationship into which they draw places. As Edson and Savage-Smith remark, however: 'Maps in early Christendom, particularly world maps, were attempts to explore theological and historical aspects of space, rather than make scale models of the physical world' (2004:.93). That methodology of making models of the physical was not invented in Europe until the late fifteenth century at the earliest.

Areas close to home might indeed be precisely known, and the relationship between places exactly understood. While this sort of knowledge might extend along main lines of communication, like the pilgrim routes to the Holy Land, clearly, without an overall agreed convention for a descriptive system, you will have an infinitude of more or less overlapping but in the last analysis distinct spatial models. To use Dick Harrison's term, this detailed, experienced, knowledge of distance and relationship may be termed 'micro-space' (1996). But the further from 'home,' the less detailed the microspatial picture will be, and the more what we may call the macrospatial, working on quite different principles, will come into operation. The familiar convention of the 'T-in-O' mappae mundi, with East at the top, and the Don, Nile and Mediterranean forming the T is well represented by the Hereford mappa mundi (c. 1285) in Hereford Cathedral, which is typical of those dating from the ninth to the sixteenth century. Such maps are 
no help to finding one's way, but perfectly coherent if we want to treat places and the world itself, and the events that occurred there, as moral symbols placed on a land space represented as a disc symmetrically and symbolically disposed around Jerusalem. On the map, full of stories and text, one finds many ideas and details of traditional moralised geography, where fundamentally the world is interpreted symbolically. As the twelfth century poet Alain de Lille put it in his poem on the Name of the Rose (Migne Patrologia Latina 1849-1855: 210 , 579a):

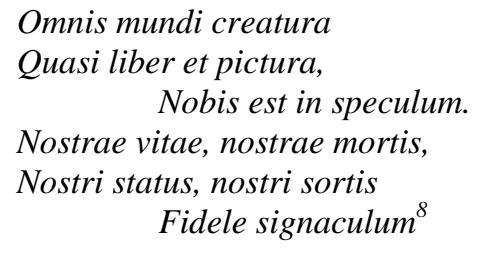

Signaculum, indeed. For on the macrospace these 'TinO' maps depict are inscribed the legends and marvels, the myths and monsters beyond the mental margins of microspace. The Hereford map must indeed be read as much as moral symbol as work of information - it is both, of course. The earth is bathed in Ocean, and at the four corners are the letters M.O.R.S.—death. The importance of these features is far less descriptive or orientational than mnemonic and moral, and historical, even ideological—this is a Christian map-within the linear model, itself moral, of Time from Creation to the Last Judgement; and that model was usual till long after the Middle Ages. The distinction is illustrated by contrasting the sea charts of the Middle Ages, the portolani, which are perfectly satisfactory tools to find your way from one haven to another-across microspace-with mappae mundi like the Hereford Map: a map of moral history, where space becomes symbol.

Literature reflects this dichotomy. The Road that Chaucer's pilgrims ride is microspace, with named and remembered places in a sequence-even so, they are on a moral and symbolic journey just as much as Langland's pilgrims. But the landscape of romance, for example King Alisaunder, or the Roman de toute chevalerie of Thomas of Kent-or the Arthurian romances-is not interested in physical sequence and circumstantial detail: the focus is on the moral tests and prowess of the hero as he leaves microspace, perhaps named with real names, for the macrospace, and it is a waste of time to try to

\footnotetext{
8 'The whole world's creation is for us a mirror, like a book or picture. It is a faithful symbol of our life, our death, our state and our fate.'
} 
make any physical map of the journeys. In exactly the same way it is a waste of time to try to put Mandeville's supposed journey on a modern map: what matters is the moral and indeed epistemological challenge the narrative gives us.

Mandeville of course has to use the usual symbolic convention-as on the Hereford mappa mundi-where Jerusalem is at the same time the centre of the world and its summit, so to speak, everything falling away from it. Yet at the same time everything has symbolically, morally fallen away from the Earthly Paradise in the remotest East. (Belief in its actual existence would persist for a good few centuries yet: Bishop P. D. Huet of Soissons, wrote on the topic in 1694, and a certain Erik Klimt defended a doctoral dissertation arguing for its physical existence in the University of Uppsala in 1714). Mandeville says he saw the Earthly Paradise in the distance, its walls covered with moss. He has to reconcile this spatial symbolism with his idea of the sphericity of the earth, and of course it is not possible. He is clearly uneasy about the problems these difficulties present, and that uneasiness, which I have found in no other account, is the first step, I think, on the way to a methodology which could resolve them. Indeed, looking at the Hereford map helps us to get an idea of the default mental map of Mandeville and his first readers, for Mandeville's methodological problem is grasped the more readily if one thinks about the problem of representing a sphere, the globe of the earth, on a plane surface. Modern map projections, invented long after Mandeville, partly solve the problem, but introduce difficulties of their own, not least the similar one of political, even cultural prioritisation. (I sometimes make my students look at a map centred on Tokyo, or one with Antarctica at the top.) Mandeville, aware as he seems to be of the methodological problem, uses his narrative with an identical moral intention, and the structure of the book that results is important.

It is in the handling of the narrator however that one must see the book's greatest originality. The first person narrative does not just give a great deal of diverse information from many different sources. It allows it to be filtered through the judgement and personality of a subtly characterised narrator, whose very intimacy with his readers is both authorising and qualifying. He paints a very fair picture of the Eastern Orthodox Church, ${ }^{9}$ as he does for the Nestorian, insisting on the coherence of their teaching, and, as they were both regarded as schismatic or heretical by the Papacy,

\footnotetext{
${ }^{9}$ Such accounts are far from common in the period.
} 
tacitly implying that Rome's position is not necessarily the only plausible one. Similarly he claims to have served in the army of the Sultan of Egypt and recounts a conversation this simple soldier had with this potentate (!) in which he describes the religion and practice of the West. ${ }^{10}$ The Sultan is then made to point out how the behaviour of Christians falls far short of the ideals they profess. Later, he gives the fullest description, remarkably balanced, of Islam to be found in the vernaculars of the time, and underlines the moral superiority of Moslems over Christians, especially in works of charity and almsgiving. He describes the cannibalism of Lamory, in the East, the Gymnosophists, polyandry, the cult of the Juggernaut—all opportunities to show the failings of Christians and the rational basis and viability of other beliefs and cultures. It is in fact a very critical, almost revolutionary, point of view that the author takes of the practice and overconfident pride of the Latin Church each time he compares pagan and Western behaviour, always to the disadvantage of easy and unconsidered certainties in Europe. In fact, the theme of the first sentences of the book is here worked out: Christians of the West are simply not fit to possess the Holy Land, and are unworthy of their religion.

Mandeville's criticism is profound but indirect. Though he praises the Greeks or the Moslems, he presents himself as a good Catholic. It must be stressed that at no time does Mandeville question the central doctrines of Christianity but it is hard to see how his first readers would not have recalled that the Bull of Boniface VIII Unam Sanctam (1302), relying on the doctrine of Innocent III (1215), and recently restated by Clement VI, said that nulla salus extra ecclesiam - 'there is no salvation outside the Church.' That Bull 'declared, said, defined and pronounced that it is absolutely necessary for the salvation of each human being that they be subject to the Roman pontiff.' This is just unfortunate, in theory, for the Moslems and the Gymnosophists, for the Greeks as for virtuous pagans like Job-who is mentioned twice at crucial points in the book. But, as Mandeville says there, 'We know not whom God loveth nor whom he hateth.'

Mandeville's book became a 'geographical' authority. It was indeed as up to date an account of the world as he knew how to make it, but one cannot ignore the fact that it has a great satiric force too. The assumed moral superiority of Europe is questioned and the customs and beliefs of the East, garbled as they may be in many cases, are used to

\footnotetext{
${ }^{10}$ There is a very similar satiric dialogue in the thirteenth century Dialogus miraculorum of Caesarius of Heisterbach, which Mandeville may have used directly or indirectly as a model.
} 
criticise social and political behaviour in the Christian world. The concept of a Nature fundamentally reasonable and explicable is equally underlined by the narrator. He rejects the tradition of the irrationally marvellous that so dominates writing about the East before him. The narrator remains circumspect, ironic, about the truth of marvels. Indeed, he is at pains to stress that what is normal and accepted in Europe might look very weird to eyes in another country who see the world from a different perspective. For example, in one of his first person stories, he describes how he was shown the Vegetable Lamb of Tartary, a great marvel, and drew an immediate parallel with the fabled genesis of barnacle geese from barnacles-a story nobody in the West questioned for another three hundred years. What is marvellous to one set of eyes is utterly usual to another. He asserts that there must be a rational explanation for the phenomenon of the fish swarming to land in Java and allowing themselves to be caught. His story of a trip past the Magnetic Rocks on a 'stitched ship,' made of planks sewn together, ${ }^{11}$ is framed by 'Someone told me ...'-no first hand assertion there. There is a better example of this careful distancing. Mandeville says he had drunk of the legendary Fountain of Youth 'three of four times.' Yet he limits himself, archly, to saying, 'It seems to me I am a little better.' And at the end of the book, there he is, old, hampered by arthritis. The personality built up through the book, sceptical, ironic, courageous and intelligent, goes a long way to explaining why this book kept its diverse readership for so very long.

It is no wonder that 'Mandeville,' fictitious as he might have been, became a figure in whom pretty universally for two centuries more and more people believed. His was an authority, factual and interpretative, unquestioned until the very late sixteenth century, when the new discoveries were forcing some people-far from all—to recognise that Mandeville's conceptual model was no longer viable. Columbus not only used the book in his preparation for the first and later voyages, but seems to have couched the very first description of the New World in terms derived from Mandeville’s. If, as I contend, that Letter to Luis Santangel—printed and circulating within days of his return-was a sort of investors' prospectus for a second voyage, Columbus had little choice but to present his account, in which he describes things he could not have seen or known, in terms that his audiences would expect from their reading of Mandeville, the chief and

\footnotetext{
${ }^{11}$ Though they were passing into memory, in Europe, such a method of construction was not uncommon when iron was very scarce: the Vikings used it. Where Mandeville sets this story, moreover, in the Arabian peninsula, such a construction method lasted into modern times. But the Magnetic Rocks, which would supposedly draw all the iron out of the ship, are a very old fable indeed (see Moseley 1968: 323).
} 
most readily available account of the East. Over a century later Walter Raleigh refers to Mandeville as an authority in the account of the Guiana Voyage, and we know Frobisher had a copy with him in 1576 when he searched for a North West Passage. Moreover, such was his renown that he had a fairly successful play written about him in the 1590s, and he takes his place with other worthies of travel like King Solomon, and Columbus, Drake, Jenkinson and Chancellor on the engraved title page of Samuel Purchas's Purchas his Pilgrimes (1613).

Detailed, factual, use of the book, however, though common for so long, is not to my mind of most interest to us. Mere enumeration of borrowed details leads nowhere. What is really important is the insight the book gives us into the sensibility and conceptual originality of a man of unusual learning living at a time of great intellectual, environmental and political upheaval. That also allows us to begin to understand how vastly different mental models of the world we live in might develop—will develop! — from what seems, for the moment, to be a stable and comprehensive picture.

\section{Editions of Mandeville's Travels}

Deluz, C. (ed.) 2000, Jean de Mandeville, Le Livre des merveilles du monde, (Coll. Sources d'Histoire Médiévale, 31). Éditions du CNRS, Paris.

Hamelius, P. (ed.) 1919 \& 1923, The Cotton Text (2 vols). Early English Text Society, London.

Letts, M. (ed.) 1953, The Egerton Text (2 vols.). Hakluyt Society, London.

Moseley, C. W. R. D. (ed.) 2005, Mandeville's Travels (translation and introduction). $2^{\text {nd }}$ ed. Penguin Books, London.

Seymour, M. C. (ed.) 1967, The Cotton Text. Oxford University Press, Oxford. 2002, The Defective Version of Mandeville's Travels. Early English Text Society, Oxford University Press, Oxford. 2010, The Egerton Version of Mandeville's Travels. Early English Text Society, Oxford University Press, Oxford.

Warner, G. (ed.) 1889, The Egerton Text. Roxburghe Club, London.

\section{Reference List}

Bennett, J. W. 1954, The Rediscovery of Sir John Mandeville. The Modern Language Association of America, New York.

Bremer, E. \& Röhl, S. (eds) 2007, Jean de Mandeville in Europa. Neue Perspektiven in der Reiseliteraturforschung, (Mittelalter Studien 12). Fink Verlag, München.

Caesarius of Heisterbach c. early $13^{\text {th }}$ century, Dialogus miraculorum.

Campbell, M. B. 1988, The Witness and the Other World: Exotic European Travel Writing 400-1600. Cornell University Press, Ithaca and London.

Deluz, C. 1988, Le Livre de Jehan de Mandeville: une "géographie" au XIVe siècle. Publications de l’Institut d'Etudes Médiévales de l’Université Catholique de Louvain, Louvain-la-Neuve.

Edson, E. \& Savage-Smith, E. 2004, Medieval Views of the Cosmos. University of Chicago Press, Chicago.

Elner, J. \& Rubiés, J-P. (eds) 1999, Voyages and Visions: Towards a Cultural History of Travel, Reaktion Books, London. 
Greenblatt, S. J. 1991, Marvellous Possessions. University of Chicago Press, Chicago. doi: http://dx.doi.org/10.7208/chicago/9780226306575.001.0001.

Harrison, D. 1996, Medieval Space: The Extent of Microspatial Knowledge in Western Europe During the Middle Ages. Lund University Press, Lund.

Higgins, I. M. 1997, Writing East: The 'Travels’ of Sir John Mandeville. University of Pennsylvania Press, Philadelphia. doi: http://dx.doi.org/10.9783/9780812202267.

Howard, D. R. 1971, 'The World of Mandeville's Travels,' Yearbook of English Studies, vol. 1: 1-17. doi: http://dx.doi.org/10.2307/3507049.

Lawton, D. 2001, 'The Surveying Subject and the “Whole World” of Belief: Three Case Studies’ in New Medieval Literatures IV, (eds) R. Copeland \& D. Lawton. Clarendon Press, Oxford: 9-37.

Letts, M. 1949, Sir John Mandeville, The Man and His Book. Batchworth Press, London.

Migne, J. P. 1849-1855, Patrologia Latina, vol. 210.

Moseley, C. W. R. D. 1968, 'Stitched Ships and Loadstone Rocks,' Notes and Queries, vol. 15, no. 9 (September): 323.

Moseley, C. W. R. D. 1974, 'The Metamorphoses of Sir John Mandeville,' Yearbook of English Studies, vol. 4: 5-25. doi: http://dx.doi.org/10.2307/3506677.

Moseley, C. W. R. D. 2011, “New Things to Speak of”: Money, Memory and Mandeville's Travels in Early Modern England,' Yearbook of English Studies, vol. 41, no. 1: 5-20. doi: http://dx.doi.org/10.5699/yearenglstud.41.1.0005.

Niayesh, L. (ed.) 2011, Mandeville and Mandevillian Lore in Early Modern England. Manchester University Press, Manchester.

Poerck, G. de 1955, 'La tradition manuscrite des Voyages de Jean de Mandeville,' Romanica Gandensia, vol. 4: 125-158.

Sacrobosco, J. c. 1230. Tractatus de Sphaera (On the Sphere of the World).

Seymour, M. C. 1961, 'The Origin of the Egerton Version of Mandeville’s Travels,' Medium Aevum, vol. 30: 159-169.

Seymour, M. C. 1993, Sir John Mandeville. (Authors of the Middle Ages, 1; English Writers of the Late Middle Ages). Variorum, Aldershot, Hampshire.

Zacher, C. K. 1976, Curiosity and Pilgrimage: The Literature of Discovery in Fourteenth-Century England. Johns Hopkins University Press, Baltimore.

Zumthor, P. 1972, Essai de poétique médiévale. Seuil, Paris. 